\title{
Stuck in time - a new Chaenothecopsis species with proliferating ascomata from Cunninghamia resin and its fossil ancestors in European amber
}

\author{
Hanna Tuovila - Alexander R. Schmidt • \\ Christina Beimforde • Heinrich Dörfelt • \\ Heinrich Grabenhorst • Jouko Rikkinen
}

Received: 15 June 2012 / Accepted: 15 October 2012 /Published online: 8 November 2012

(C) The Author(s) 2012. This article is published with open access at Springerlink.com

\begin{abstract}
Resin protects wounded trees from microbial infection, but also provides a suitable substrate for the growth of highly specialized fungi. Chaenothecopsis proliferatus is described growing on resin of Cunninghamia lanceolata from Hunan Province, China. The new fungus is compared with extant species and two new fossil specimens from Eocene Baltic and Oligocene Bitterfeld ambers. The Oligocene fossil had produced proliferating ascomata identical to those of the newly described species and to other extant species of the same lineage. This morphology may represent an adaptation to growing near active resin flows: the proliferating ascomata can effectively rejuvenate if partially overrun by fresh, sticky exudate. Inward growth of fungal hyphae into resin has only been documented from Cenozoic amber fossils suggesting comparatively late occupation of resin as substrate by fungi. Still, resinicolous Chaenothecopsis species were already well adapted to their special ecological niche by the Eocene, and the morphology of these fungi has since remained remarkably constant.
\end{abstract}

H. Tuovila $\cdot$ J. Rikkinen $(\bowtie)$

Department of Biosciences, University of Helsinki,

P.O. Box 65, 00014 Helsinki, Finland

e-mail: jouko.rikkinen@helsinki.fi

A. R. Schmidt • C. Beimforde

Courant Research Centre Geobiology,

Georg-August-Universität Göttingen,

Goldschmidtstraße 3,

37077 Göttingen, Germany

\section{H. Dörfelt}

Mikrobielle Phytopathologie, Friedrich-Schiller-Universität Jena,

Neugasse 25, 07743 Jena, Germany

H. Grabenhorst

Nachtigallenweg 9,

29342 Wienhausen, Germany
Keywords Fossil fungi · Proliferating ascomata $\cdot$ Resin compounds $\cdot$ Ecology $\cdot$ Taxonomy

\section{Introduction}

Resinous exudates provide plants with protection against pathogens and parasites, but some highly specialized fungi are also known to grow exclusively on resin substrates. In the Mycocaliciales Tibell \& Wedin (Eurotiomycetes, Ascomycota) some $10 \%$ of the approximately 150 known species grow on plant exudates (Tibell and Titov 1995; Rikkinen 1999, 2003a; Titov 2006; Tuovila et al. 2011a, 2011b). Most of these fungi live on conifers and produce perennial, stipitate ascomata on hardened resin and/or resin-impregnated wood. Some species are also able to colonize relatively fresh, semisolid resin. The ability to rapidly exploit new substrates is advantageous, but also carries the inherent risk of being buried by subsequent resin flows. This danger is well exemplified, not only by the occurrence of partially or completely submerged ascomata in modern resins, but also by submerged specimens in European amber dating back to the Oligocene (Rikkinen and Poinar 2000) and Eocene (this study).

Here, we describe a new resinicolous Chaenothecopsis species from the exudate of Cunninghamia lanceolata (Lamb.) Hook. (Cupressaceae) from Hunan Province, China, as well as newly discovered Chaenothecopsis fossils from Eocene Baltic and Oligocene Bitterfeld ambers dating back to at least 35 and $24 \mathrm{Ma}$ ago, respectively. The exquisite preservation of the fossils allows a detailed comparison with extant relatives. One fossil fungus has produced branched and proliferating ascomata similar to those of the newly described species from China, as well as some other extant species of the same lineage. 


\section{Material and methods}

Extant and fossil fungi

Resinicolous fungi were collected from tree trunks of Cunninghamia lanceolata (Cupressaceae), Ailanthus altissima (Mill.) Swingle (Simaroubaceae), Kalopanax septemlobus (Thunb.) Koidz (Araliaceae), and Pinus massoniana Lamb. (Pinaceae) in warm temperate evergreen broadleaved forests in Zhangjiajie National Forest Park in 1999, Badagongshan National Nature Reserve in 1999 and 2000, Daweishan National Forest Park in 2000, and Shunhuangshan National Forest Park in 2001 of Hunan Province in south-central China. For more information on the study area, see Koponen et al. (2000, 2004).

The fossils with proliferating ascocarps (Fig. 7) are preserved attached to wood debris in a $17 \times 13 \times 5 \mathrm{~mm}$ piece of Bitterfeld amber from the Heinrich Grabenhorst collection (collection number Li-83) that is now housed in the Geoscientific Collections of the Georg August University Göttingen (collection number GZG.BST.27285). Bitterfeld amber originates from the Goitzsche mine near the city of Bitterfeld (central Germany) and was recovered from the "Bernsteinschluff" Horizon in the upper part of the Cottbus Formation. The Upper Oligocene amber-bearing sediment has an absolute age of 25.3-23.8 Ma (Blumenstengel 2004; Knuth et al. 2002). A previous notion that Bitterfeld amber either represents re-deposited Eocene Baltic amber, or is at least much older than the amber-bearing strata (Weitschat 1997) was disproven by recent reconstructions of the sedimentary environment of this huge amber deposit (see Standke 2008, and discussion in Schmidt and Dörfelt 2007, and Dunlop 2010).

The non-proliferating fossil ascocarps (Figs. 8 and 9) are enclosed in a $2.5 \times 1.5 \times 1 \mathrm{~cm}$ piece of Baltic amber from the Jörg Wunderlich collection (collection number F1178/BB/ FUN/CJW) that is now housed in the Geoscientific Collections of the Georg August University Göttingen (collection number GZG.BST.27286). Four immature and six mature ascomata derive from a mycelium that directly grew on the surface of a stalactite-like resin piece which served as substrate for the resinicolous fungus. These were preserved by a subsequent resin flow that had then covered over the material. The Eocene sediments containing the majority of Baltic amber in the Kaliningrad area (Russia) are 35-47 Ma old (Standke 1998).

Microscopy, imaging and microanalysis

Morphological features of the extant fungal specimens were observed and measured in water under a light microscope (Leica DMLS) with a $100 \mathrm{x}$ oil-immersion objective. Potassium-hydroxide (KOH), Lugol's reagent (IKI), Melzer's reagent (MLZ), Congo Red (CR; CR + congophilous, coloring strongly red in $\mathrm{CR}$ ), and nitric acid (N) were used when observing some diagnostic structures, like paraphyses and stipe hyphae. Ascomata from dried Cunninghamia bark pieces were imaged under a Carl Zeiss AxioScope A1 compound microscope using simultaneously incident and transmitted light. Spores were imaged on a microscope slide in water using 1600× (oil immersion) magnification and Differential Interference Contrast (DIC) illumination.

For scanning electron microscopy, several dried specimens of C. proliferatus were removed from the substrate, placed on a carbon-covered SEM-mount, sputtered by gold/ palladium and examined under a Carl Zeiss LEO 1530 Gemini field emission scanning-electron microscope as described by Beimforde et al. (2011). Energy-dispersive X-ray spectroscopy (EDX) was performed on some ascomata using an INCA-EDX system (Oxford Instruments) with an excitation voltage of $15 \mathrm{KV}$ at this electron microscope.

The amber pieces were ground and polished manually with a series of wet silicon carbide abrasive papers to remove the weathered crusts and to minimize light scattering for the investigation. Prepared specimens were placed on a glass microscope slide with a drop of water applied to the upper surface of the amber, and covered with a glass coverslip. The inclusions were studied using a Carl Zeiss AxioScope A1 compound microscope. In most instances, incident and transmitted light were used simultaneously (see Schmidt et al. 2012, for protocols). In order to protect the amber from oxidation and breakage, the polished Baltic amber piece was embedded using polyester resin as described by Hoffeins (2001).

The images of Figs. 1, 2, 7, 8 and 9 (with exception of Figs. 2e, 7g, and 9f, g) are digitally-stacked photomicrographic composites obtained from several focal planes using the software package HeliconFocus 5.0 for a better illustration of the three-dimensional objects.

DNA extraction, PCR amplification and sequencing

DNA was extracted from extant representative specimens of resinicolous fungi collected from Hunan Province. Additional resinicolous, lignicolous and parasitic fungi were collected from different localities in Finland (2009) and northwestern USA (2006). DNA was extracted from 5 to 10 ascomata of each species with the NucleoSpin@Plant DNA extraction kit (Macherey-Nagel) with the following modification to the manufacturer's protocol: specimens were incubated for $2 \mathrm{~h}$ to ensure the lysis of the ascocarps. The nuclear large subunit ribosomal RNA (LSU) partial gene was amplified using the primers LR0R and LR3 (Rehner and Samuels 1994; Vilgalys and Hester 1990). The ITS region of rDNA was amplified using the primers ITS4 and ITS5 (White et al. 1990) or alternatively ITS4 and ITS1F (Gardes and Bruns 1993). PCR amplification was conducted using Phusion ${ }^{\circledR}$ HighFidelity DNA Polymerase (Thermo scientific/Finnzymes) 

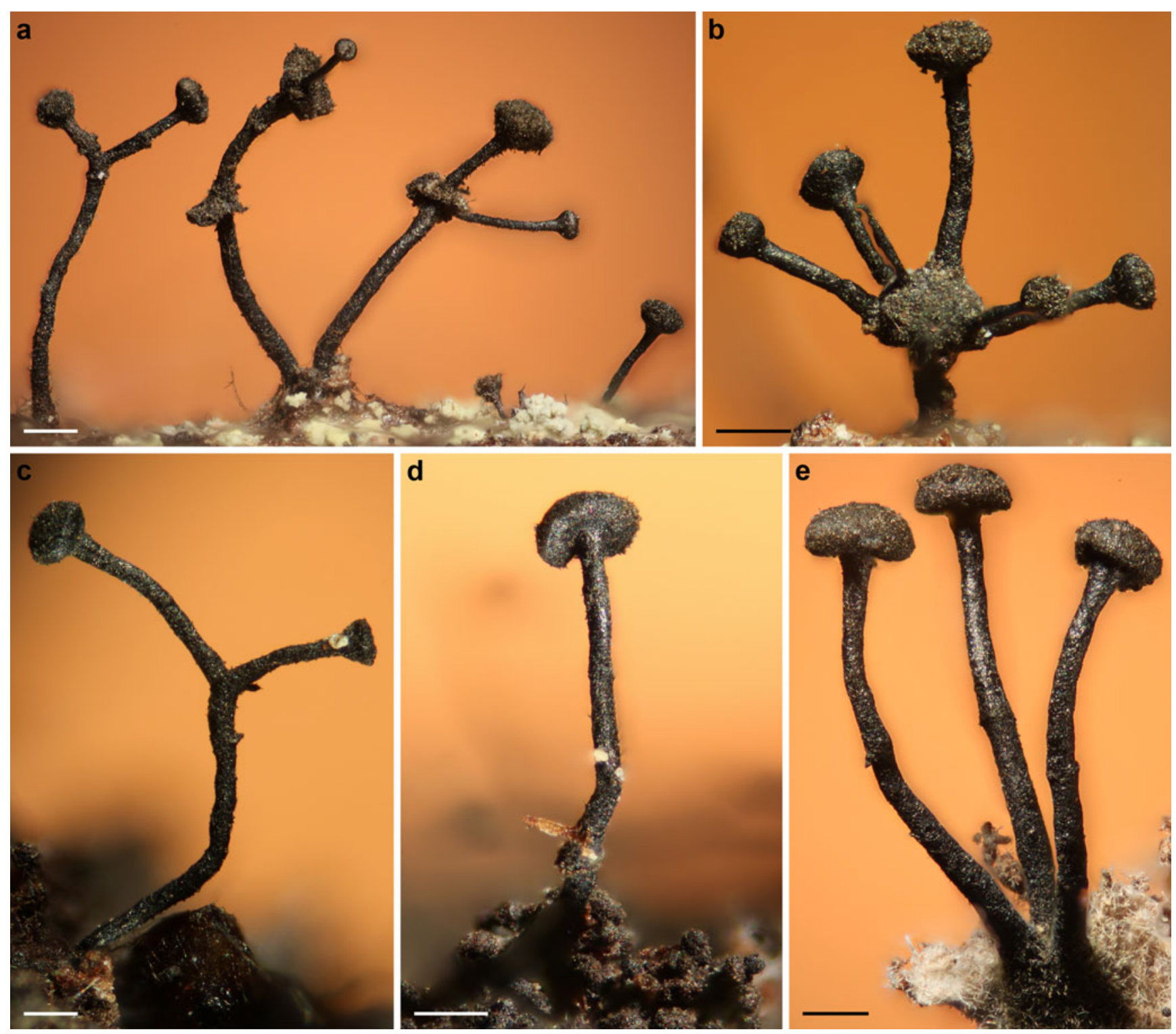

Fig. 1 Ascomata of Chaenothecopsis proliferatus sp. nov. on resinimpregnated bark of Cunninghamia lanceolata a Proliferating ascomata (JR 990048). b Multiple branching from capitulum (holotype, JR 990061). c Ascoma with branched stipe (holotype, JR 990061).

according to the manufacturer's specifications using a 1:4 dilution of template DNA. PCR products were purified with GeneJET $^{\text {TM }}$ PCR Purification Kit (Fermentas). Amplicons were sequenced by Macrogen Inc. (South Korea) in the forward and reverse directions using the same primers as during amplification. Sequences for each sample were assembled into contigs using Geneious v5.4 (Drummond et al. 2011) and the consensus sequences used for further analyses. For samples that failed to amplify using the Phusion PCR method, amplification was conducted using PuReTaq Ready-To-Go PCR Beads (GE Healthcare, Piscataway NJ, USA) according to the manufacturer's instructions with the primers LROR \& LR7 (Vilgalys and Hester 1990) or ITS1F \& ITS4, and $3 \mu \mathrm{L}$ d Mature non-branched ascoma on resin (holotype, JR 990061). e Non-branched ascomata rising from a common stroma; note dense aerial mycelium (holotype, JR 990061). Scale bars: $200 \mu \mathrm{m}$

of template DNA in a total PCR reaction volume of $25 \mu \mathrm{L}$. These amplicons were then sequenced using an ABI 3100 automated sequencer (Applied Biosystems Inc., Foster City, CA, USA) with the primers ITS1F \& ITS4, and LROR, LR3, LR5, and LR7.

\section{Phylogenetic analyses}

A concatenated dataset was composed of both the ITS and LSU sequences that were generated, and previous accessions from NCBI GenBank. The GenBank sequences were selected following two criteria: both ITS and LSU sequences were from the same voucher material (with the 

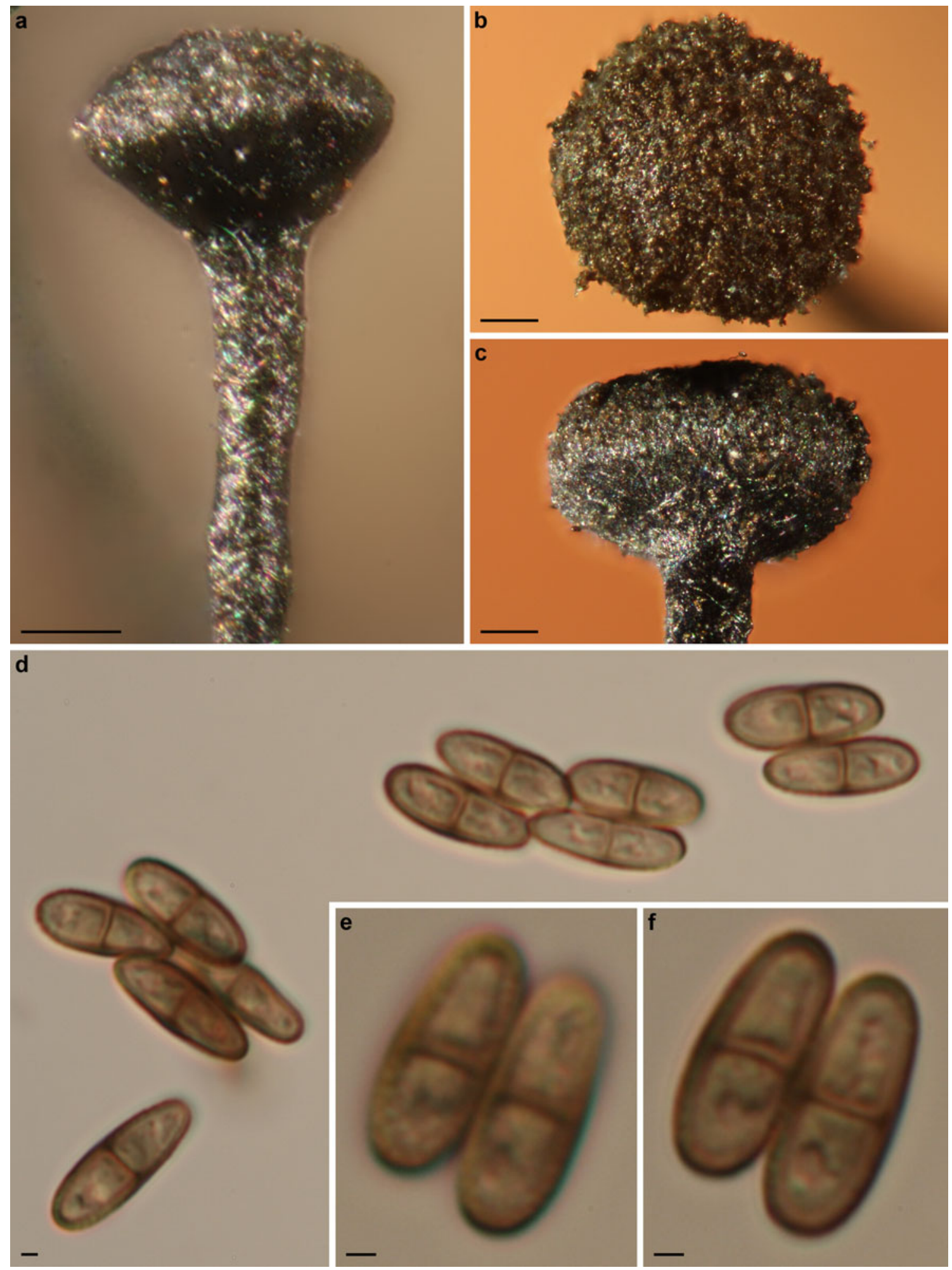

Fig. 2 Capitulum and spores of Chaenothecopsis proliferatus sp. nov. (holotype, JR 990061). a Young capitulum and upper section of stipe; note intertwined surface hyphae. b Capitulum with thin mazaedium

exception of Mycocalicium sequoiae from which only the LSU sequence was available), and sequences were from species with unequivocal taxonomic status. The dataset seen from above. c Exciple. d Ascospores. e Spore wall in focus. f Septum in focus. Scale bars: $50 \mu \mathrm{m}(\mathbf{a}-\mathbf{c})$ and $1 \mu \mathrm{m}(\mathbf{d}-\mathbf{f})$

was aligned with MAFFT version 6 (Katoh and Toh 2008) and adjusted manually in $\mathrm{PhyDE}^{\circledR} 0.9971$ (Müller et al. 2010). Unequivocal short (1-3 nucleotides) uninformative 
insertions were first removed from the alignment, and the program Gblocks 0.91 (Castresana 2000) was then used to remove ambiguously aligned regions. Phylogenetic relationships and confidence statistics were inferred using a partitioned Bayesian approach in which models of evolution were generated independently with jModeltest 1.1 (Posada 2008) for each of the gene regions (LSU, ITS1, 5.8S, ITS2). The suggested evolutionary models (TIM2ef + G, HKY + G, TIM2ef + G, TIM3ef + G, respectively) were implied for the partitioned dataset.

Bayesian analyses were carried out with MrBayes 3.1.2 (Ronquist and Huelsenbeck 2003) on the freely available computational resource Bioportal at the University of Oslo (http://www.bioportal.uio.no; Kumar et al. 2009). Two independent runs, each with four chains, were conducted simultaneously for 10 million generations with trees sampled every 100th generation. Average standard deviations of split frequency (ASDSF) values lower than 0.01 were taken as an indication that convergence had been achieved. Five percent of the sampled trees were discarded as burnin and the remaining trees were used to estimate branch lengths and posterior probabilities. Additional support values were estimated using the same model parameters in Garli 2.0 for maximum likelihood (Zwickl 2006) with 1,000 bootstrap searchreps.

Voucher information and GenBank accession numbers of all fungal specimens used in this study are listed in Table 1.

\section{Results}

Extant fungus from China

Chaenothecopsis proliferatus Rikkinen, A. R. Schmidt et Tuovila sp. nov.

Figures 1, 2, 3, 4 and 5

MycoBank no.: MB800706

Type: China. Hunan Province. Dayong County, Zhangjiajie National Forest Park. Fuqiyan, along trail to view point above Zhangjiajie Hotel; young mixed Cunninghamiaangiosperm forest with large remnant Pinus massoniana. On resin, resin-soaked bark, and lignum of Cunninghamia lanceolata. 15.IX.1999, $29^{\circ} 19^{\prime} \mathrm{N}, 110^{\circ} 25^{\prime} \mathrm{E}$, elev. $650 \mathrm{~m}$, Rikkinen JR990061 (holotype H).

Etymology: proliferatus refers to the common production of branched and proliferating ascocarps in this species.

\section{Description}

Apothecia on resin or resin-soaked wood and bark of Cunninghamia lanceolata, small to medium, 800$2,000 \mu \mathrm{m}$ high, black with a bluish tinge. Stipe shiny black, long and slender, occasionally branching, 30-80 $\mu \mathrm{m}$ wide.
Capitulum discoid to lentil-shaped, rarely subspheric or ovoid, bluish black, $170-250 \times 300-400 \mu \mathrm{m}$. Young capitulum shiny, later spores accumulate as agglomerates on top of capitulum, appearing as black spots. Old capitulum covered with brown hyphae that possibly originate from germinated spores. New apothecia proliferate often from old capitula, usually several from the same capitulum. All parts of apothecium N- and MLZ-. Asci arise from croziers, cylindrical, 64.0-81.0 $\times 3.5-4.5 \mu \mathrm{m}(n=10)$, apex variously thickened and often penetrated by a short canal, mature asci sometimes without thickening. Hymenium and hypothecium IKI+, reaction fast and only seen by adding fresh IKI to a partly dried water squash preparation while observing through the microscope. The blue reaction usually disappears in seconds after the IKI has penetrated the material, the speed and the strength of the reaction seems to vary depending on the age and pigmentation of the ascocarp. Ascospores uniseriately and periclinally arranged, sometimes partly obliquely arranged in asci, brownish green, cylindrical to fusoid, one-septate, in mature spores septum as thick as spore wall, the spore wall inwardly thickened at junction between septum and spore wall; (7.2-) 7.5-11.3 (-11.8)×3.1-4.3 (-4.6); mean 10.3× $3.4 \mu \mathrm{m}(n=90$, from 9 ascocarps, 6 populations); $\mathrm{Q}=1.9$ $3.6 \mu \mathrm{m}$, mean $\mathrm{Q}=3.0$. Spores smooth under the light microscope, but each examined ascocarp typically had a small ratio (less than $15 \%$ ) of young spores with very minute, pointed ornamentation. Paraphyses hyaline, filiform, $65-85 \times 1.0$ $1.5 \mu \mathrm{m}$, occasionally branching from lower sections, commonly branching at the ascus tip level; septate, septal intervals 5.0-15.0 $\mu \mathrm{m}$. Paraphyse tips covered with hyaline, strongly congophilous crystals that dissolve with $\mathrm{KOH}$. Hypothecium hyaline to light green. Exciple green to brownish green in young apothecia, dark (greenish) brown in older ones, hyphae parallel, 3.0-4.0 $\mu \mathrm{m}$ wide, cell wall $0.5-1.5 \mu \mathrm{m}$, often with colorless crystals between and on top of hyphae of exciple, dissolving in $\mathrm{KOH}$ and MLZ; $\mathrm{KOH}+$ yellowish brown color leaks into medium and green pigments turn brown. Faint, but persisting grayish red to purplish pink IKI + reaction in thickwalled hyphae of exciple. Reaction is often difficult to observe due to the strong pigmentation of hyphal walls. Stipe dark green in young apothecia to dark brown in older ones, hyphae more or less parallel, partly intertwined, 3.0-5.0 $\mu \mathrm{m}$ wide, cell wall 1.5-2.0 $\mu \mathrm{m}, \mathrm{KOH}+$ dark brown color leaks into medium and green colors of stipe turn brown. All parts of exciple and stipe covered with dense net of arching and horizontal hyphae $3.0 \mu \mathrm{m}$ wide, cell wall $0.5-1.0 \mu \mathrm{m}$. Epithecium greenish to yellowish brown, composed of elements from exciple and paraphyses. The thick-walled hyphae of exciple cover the asci, intertwine and form a tight net that is hard to break, with small holes measuring $3.0 \mu \mathrm{m} \times 4.0 \mu \mathrm{m}$. Paraphyses curve at the level of ascus tips to cover the asci, branch repeatedly and anastomose with neighboring branches of the same and adjoining paraphyses just beneath the net of excipular hyphae, 
Table 1 Voucher information and NCBI GenBank accession numbers for the fungal ITS and LSU sequences used in the study

\begin{tabular}{|c|c|c|}
\hline Species & $\begin{array}{l}\text { GenBank Accession } \\
\text { numbers ITS/LSU }\end{array}$ & Reference ITS/LSU, if not same \\
\hline Pyrgillus javanicus Nyl. & DQ826741/DQ823103 & James et al. 2006 \\
\hline Caliciopsis sp. & GQ259981/GQ259980 & Pratibha et al. 2011 \\
\hline Chaenothecopsis consociata (Násdv.) A.F.W.Schmidt & AY795851/DQ008999 & Tibell and Vinuesa 2005 \\
\hline Chaenothecopsis debilis (Sm.) Tibell & AY795852/AY795991 & Tibell and Vinuesa 2005 \\
\hline Chaenothecopsis diabolica Rikkinen \& Tuovila & JX119109/JX119114 & this study \\
\hline Chaenothecopsis dolichocephala Titov & AY795854/AY795993 & Tibell and Vinuesa 2005 \\
\hline Chaenothecopsis fennica (Laurila) Tibell & AY795857/AY795995 & Tibell and Vinuesa 2005 \\
\hline Chaenothecopsis golubkovae Tibell \& Titov & AY795859/AY795996 & Tibell and Vinuesa 2005 \\
\hline Chaenothecopsis khayensis Rikkinen \& Tuovila & JX122785/HQ172895 & this study/Tuovila et al. 2011a \\
\hline Chaenothecopsis montana Rikkinen & JX119105/JX119114 & this study \\
\hline Chaenothecopsis nigripunctata Rikkinen & JX119103/JX119112 & this study \\
\hline $\begin{array}{l}\text { Chaenothecopsis proliferatus Rikkinen, } \\
\text { A.R.Schmidt \& Tuovila }\end{array}$ & $-/ J X 122783$ & this study \\
\hline Chaenothecopsis pusiola (Ach.) Vain & JX119106/JX119115 & this study \\
\hline Chaenothecopsis sitchensis Rikkinen & JX119102/JX119111 & this study \\
\hline Chaenothecopsis tsugae Rikkinen & JX119104/JX119113 & this study \\
\hline Chaenothecopsis vainioana (Nádv.) Tibell & JX119107/JX119116 & this study \\
\hline Chaenothecopsis viridireagens (Násdv.) A.F.W.Schmidt & JX119108/JX119117 & this study \\
\hline Chaenothecopsis pallida Rikkinen \& Tuovila (ined.) & JX122779/JX122781 & this study \\
\hline Chaenothecopsis hunanensis Rikkinen \& Tuovila (ined.) & JR990061/JX122784 & this study \\
\hline Chaenothecopsis resinophila Rikkinen \& Tuovila (ined.) & JX122780/JX122782 & this study \\
\hline Chaenothecopsis sp. & JX119110/JX119119 & this study \\
\hline Phaeocalicium polyporaeum (Nyl.) Tibell ${ }^{\text {a }}$ & AY789363/AY789362 & Wang et al. 2005 \\
\hline Mycocalicium sequoiae Bonar & $-/ A Y 796002$ & Tibell and Vinuesa 2005 \\
\hline Mycocalicium subtile (Pers) Szatala & AF225445/AY796003 & $\begin{array}{l}\text { Vinuesa et al. 2001/Tibell } \\
\text { and Vinuesa 2005 }\end{array}$ \\
\hline Phaeocalicium populneum (Brond ex Duby) A.F.W. Schmidt & AY795874/AY796009 & Tibell and Vinuesa 2005 \\
\hline Sphinctrina leucopoda Nyl. & AY795875/AY796006 & Tibell and Vinuesa 2005 \\
\hline Sphinctrina turbinata (Pers. ex Fr.) de Not & AY795877/DQ009001 & Tibell and Vinuesa 2005 \\
\hline Stenocybe pullatula (Ach.) Stein & AY795878/AY796008 & Tibell and Vinuesa 2005 \\
\hline
\end{tabular}

${ }^{\text {a }}$ Deposited as Mycocalicium polyporaeum (Nyl.) Vain

forming an inner layer of the epithecium. This complex contains innumerable colorless, strongly congophilous crystals. Crystals also appear between paraphyses and asci, usually as a 15-20 $\mu \mathrm{m}$ thick layer. The crystals dissolve and green colors of epithecium turn brown in $\mathrm{KOH}$. Faint, but persisting grayish red to purplish pink IKI + reaction in thick-walled hyphae of epithecium, usually difficult to observe due to the dark pigmentation of cell walls.

\section{Specimens studied}

China. Hunan Province. Resinicolous on basal trunk of Cunninghamia lanceolata. Dayong Co., Zhangjiajie National Forest Park. Dense mixed Cunninghamia-angiosperm forest along roadside in moist valley, 15.IX.1999. $29^{\circ} 19^{\prime} \mathrm{N}, 110^{\circ} 24^{\prime} \mathrm{E}$, elev. $785 \mathrm{~m}$, Rikkinen
JR990047 (UPS), JR990048 (H). Moist evergreen forest with bamboo and conifer stands in valley below Zhangjiajie Hotel, 18.IX.1999, $29^{\circ} 19^{\prime} \mathrm{N}, 110^{\circ} 25^{\prime} \mathrm{E}$. Elevation $630 \mathrm{~m}$, Rikkinen JR990312, JR990346 (SKLM). Yaozizhai, along lowest section of trail from valley bottom towards the peak, mature Cunninghamia lanceolata plantation along dry stream bed, 20.IX.1999, $29^{\circ} 18^{\prime} \mathrm{N}, 110^{\circ} 25^{\prime} \mathrm{E}$, elev. 610 m, Rikkinen JR990484. Liu Yang Co., Daweishan National Forest Park. Xu-Quan $\mathrm{Hu}$, low broadleaved secondary thickets with isolated Cunninghamia lanceolata in moist valley, 28.IX.2000, $28^{\circ} 25.30^{\prime} \mathrm{N}, 114^{\circ} 06.95^{\prime} \mathrm{E}$, elev. ca. $1,300 \mathrm{~m}$, Rikkinen $J R 000470(\mathrm{H})$. Lower section of trail from Li-Mu-Qiao to Wu-Zi-Shi crossing, secondary mixed evergreen forest with bamboo stands on steep slope of moist river valley, 28.IX.2000, $28^{\circ} 25.50^{\prime} \mathrm{N}, 114^{\circ} 05.35^{\prime} \mathrm{E}$, elev. ca. $1,000 \mathrm{~m}$, 


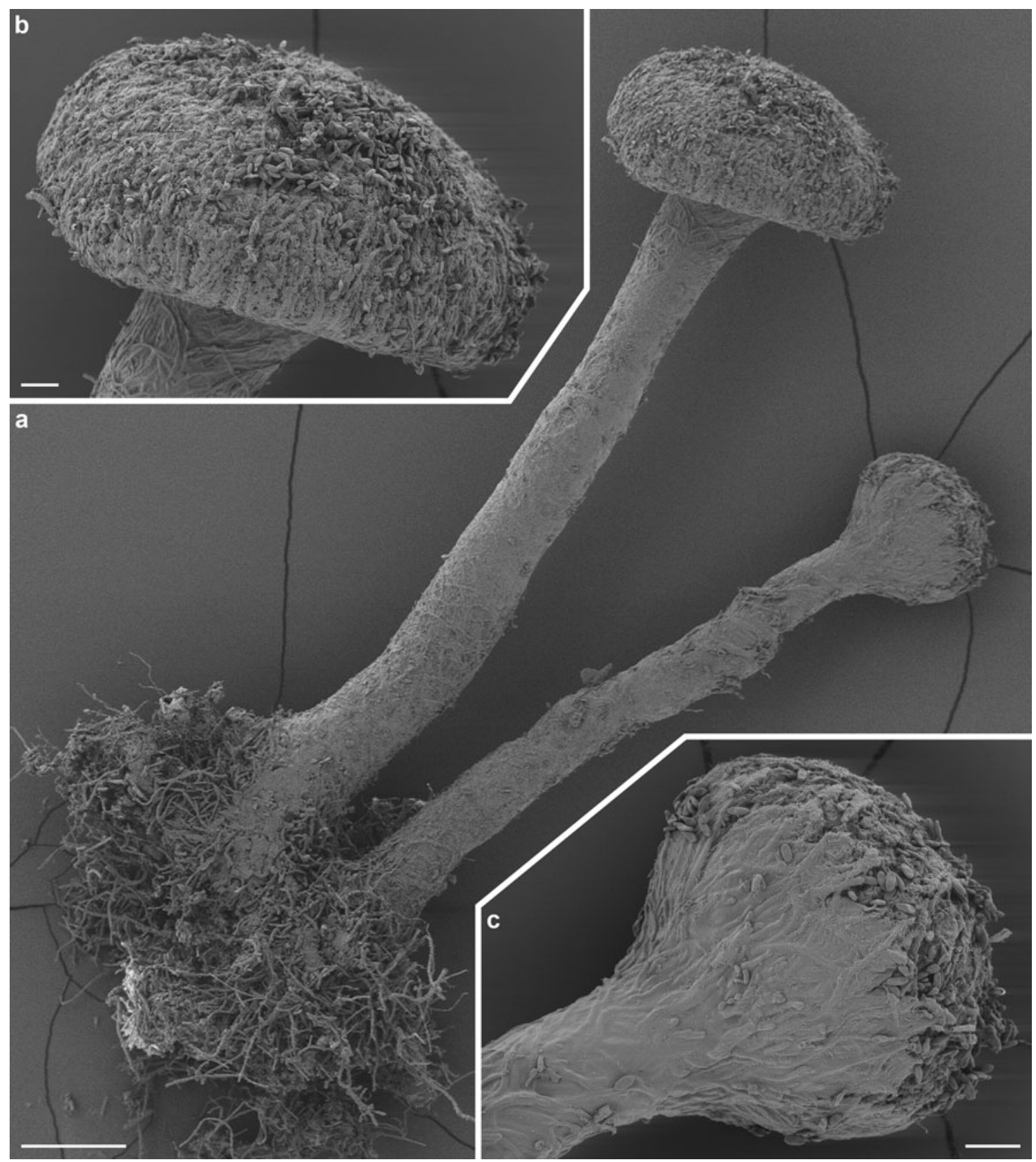

Fig. 3 SEM images of ascomata of Chaenothecopsis proliferatus sp. nov. (holotype, JR 990061). a Ascomata. b Detail of epithecium. c Detail of exciple. Scale bars: $100 \mu \mathrm{m}$ (a) and $20 \mu \mathrm{m}$ (b and c)

Rikkinen JR000594, JR000595 (H). Xinning Co., Shunhuangshan National Forest Park. Zheng Jiang Valley. Cunninghamia lanceolata/Trachycarpus fortunei stand in grazed mixed evergreen secondary forest, 24.IX.2001, 26² $24^{\prime}$ $35^{\prime \prime} \mathrm{N}, 110^{\circ} 59^{\prime 2} 20^{\prime \prime}$ E, elev. 950 m, Rikkinen JR010543 (H).

\section{Phylogenetic analysis}

The fungal LSU and ITS sequences obtained from extant Chaenothecopsis specimens in this study and from
GenBank were highly variable. There were no major indels in the LSU and $5.8 \mathrm{~S}$ sequences, so these regions could be unambiguously aligned with Mafft. Conversely, the ITS1 and ITS2 sequences of most species had several apparently independent indels; in some cases tens of nucleotides long. Such unambiguous regions were removed before analysis. The lengths of sequences used in the phylogentic analyses were: ITS1 $137 \mathrm{bp}$ (60\% of the original 227 positions), 5.8SR 155 bp (99\% of 156 positions), ITS2 130 bp (54\% of 238 positions), and partial LSU 534 bp (97\% of 548 

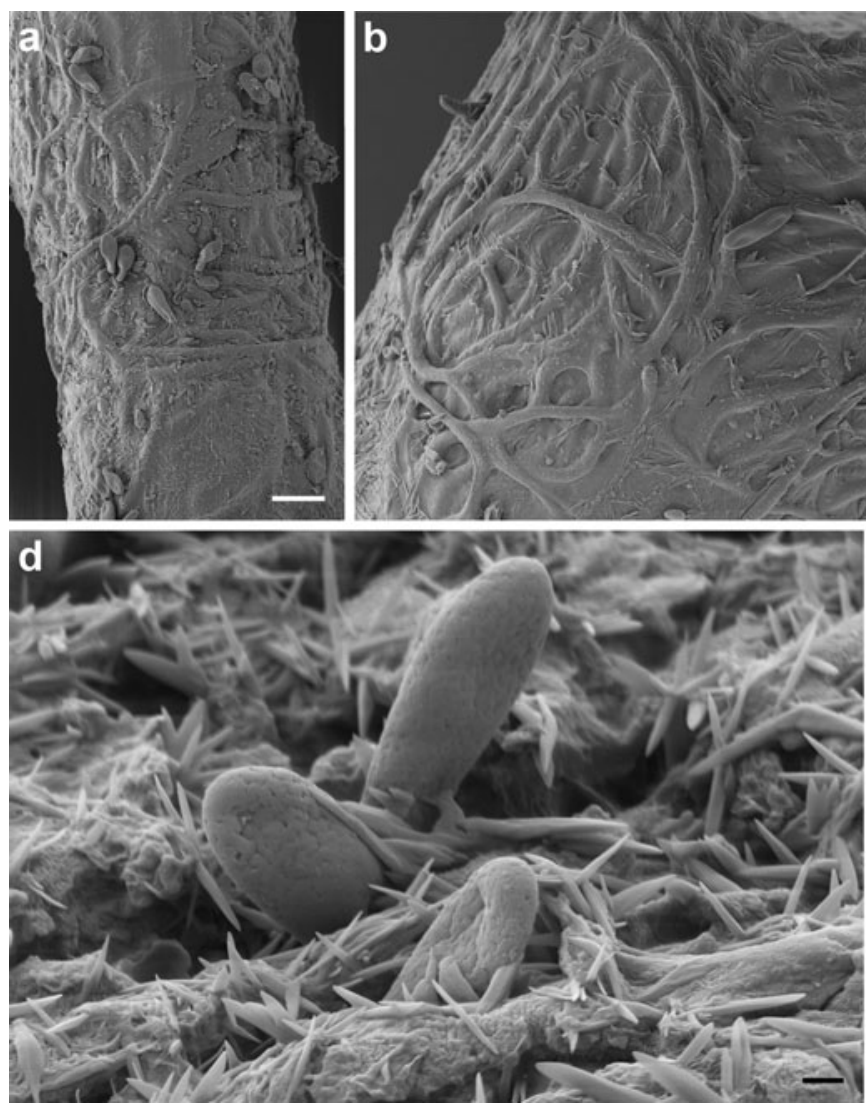

Fig. 4 SEM images showing anatomical details of Chaenothecopsis proliferatus sp. nov. (holotype, JR 990061). a Stipe surface. b Stipe surface near exciple. c Epithecium. d Ascospores being released

positions). The resulting alignment has been uploaded to TreeBase, direct accession: http://purl.org/phylo/treebase/ phylows/study/TB2:S12780.

The results of the phylogenetic analysis are shown in Fig. 6. The phylogeny is broadly consistent and adds to the previous results of Tibell and Vinuesa (2005) and Tuovila et al. (2011a). It places C. proliferatus in the same clade with several other Chaenothecopsis species with one-septate spores. This clade includes taxa that grow on conifer resins, a species that grows on conifer lignum, and several species that are either lichen-parasitic or associate with free-living green algae.

Chaenothecopsis proliferatus and the closely related $C$. hunanesis Rikkinen \& Tuovila (ined.) had a negative effect on the posterior probabilities of the tree. If these species were removed from the dataset, the other species showed qualitatively similar groupings with higher posterior probabilities (tree not shown). This is probably explained by the fact that only LSU sequences were available for these two new species from China; presumably due to the relatively old age of the specimens (over 10 years), we were not able to amplify ITS sequences from them. Without information from ITS sequences, there is a level
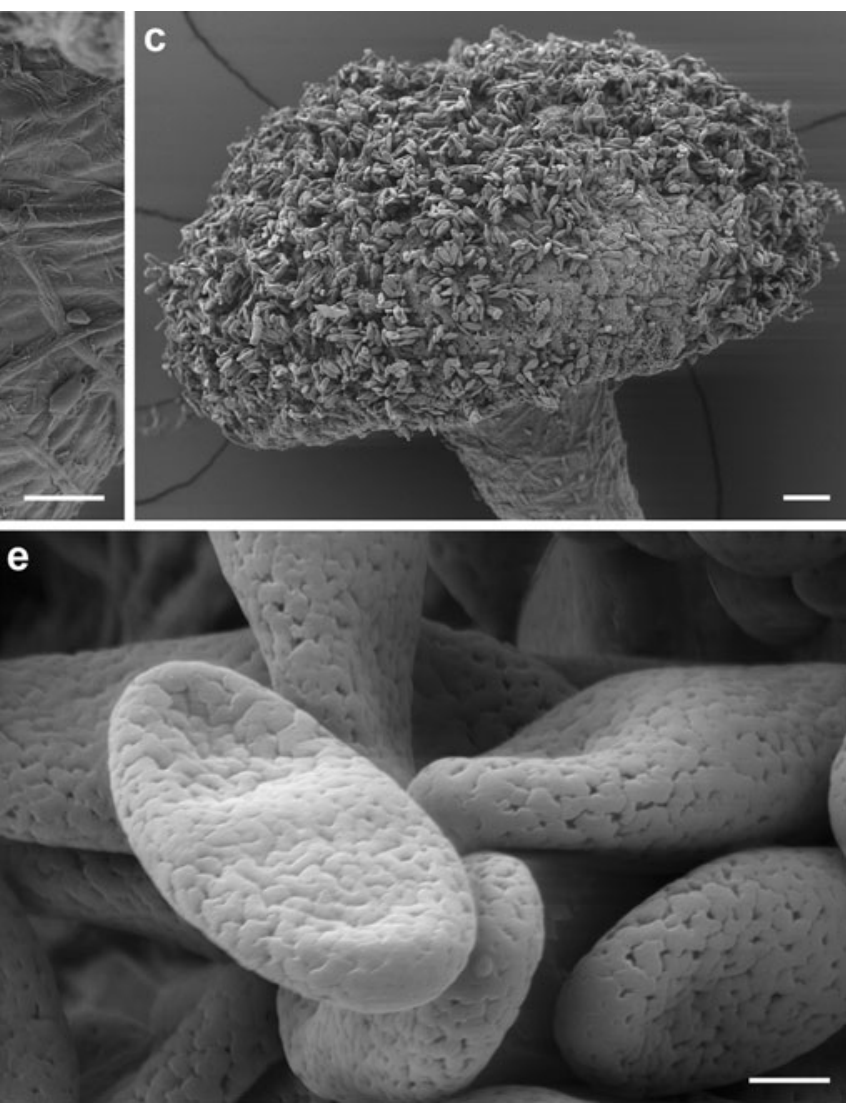

through the epithecium; note the blade-like crystals. e Ascospores. Scale bars: $10 \mu \mathrm{m}$ (a and b), $20 \mu \mathrm{m}$ (c) and $1 \mu \mathrm{m}$ (d and e)

of uncertainty regarding the exact placement of these two taxa within their clade. In an analysis based solely on LSU sequences, the sister group relationship between the four lichen-parasitic taxa and the clade of $C$. dolichocephala, $C$. sitchensis and $C$. fennica gained higher support, but the placement of $C$. proliferatus remained unresolved (tree not shown).

Fossil specimens from European amber

Amber piece GZG.BST.27285 (Bitterfeld amber) contains fossilized remains of over 45 stipitate fungal ascomata (Fig. 7a-b). These represent different developmental stages from young initials to mature and senescent ascomata. Individual ascomata erect, $250-1100 \mu \mathrm{m}$ high, forming stacks of up to three ascomata of different ages by proliferating and branching (Fig. 7a-c). Exciple well-developed, smooth, with partly intertwined surface hyphae (Fig. 7d-e). Stipe slender, 30$80 \mu \mathrm{m}$ in diameter, smooth, with partly intertwined hyphae (Fig. 7b-d). Tufts of anchoring hyphae penetrate the substrate (Fig. 7a-b). Ascospores narrowly ellipsoidal to cylindrical, one-septate, 9-10.5 $\times 3.5-4.5 \mu \mathrm{m}$, appearing smooth under the light microscope (Fig. 7f-g). 


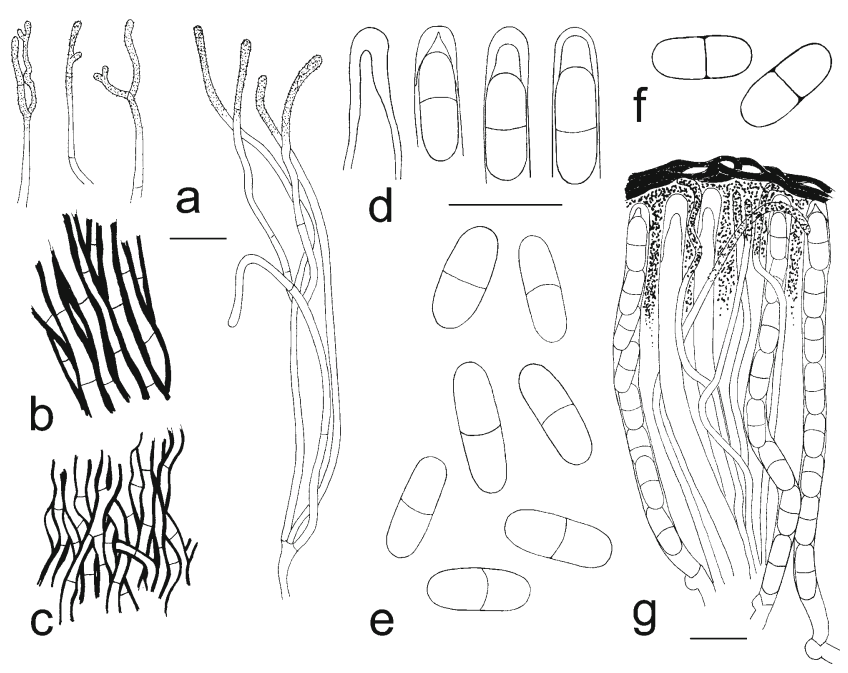

Fig. 5 Line drawings of anatomical details of Chaenothecopsis proliferatus sp. nov. (in water and CR). a Paraphyses (JR990346, JR000595). b Stipe (JR990048). c Exciple (JR990048). d Ascus tip (JR990061, JR000595). e Ascospores (JR990048, JR990061, JR990312, JR000595). f Spore wall (JR990312). g Paraphyses, asci, and epithecium (JR000593). Scale bars: $10 \mu \mathrm{m}$. Drawing by HT
Amber piece GZG.BST.27286 (Baltic amber) contains fossilized remains of at least 15 stipitate fungal ascomata (Fig. 8a). These include ten well-preserved ascomata (4 immature, 6 mature) and at least five degraded ascomata. Many details not visible due to weathered crust around the latter inclusions. Ascomata erect and non-branching, 1,500-1,840 $\mu \mathrm{m}$ high when mature (Figs. 8a, 9a). Immature, developing ascomata with sharply pointed apices (Fig. 9b-c). Capitula lenticular to subhemispheric, $260-380 \mu \mathrm{m}$ wide and 120-200 $\mu \mathrm{m}$ high, with a well-developed exciple (Fig. 9a). Mature ascospores have accumulated on top of epithecium (Fig. 9d). Stipe long and rather robust, 90-160 $\mu \mathrm{m}$ in diameter, smooth or with a somewhat uneven surface of partly intertwined hyphae. (Fine details not visible due to thin film of air around the inclusions) (Fig. 9a-e). Tufts of anchoring hyphae attach the ascomata to the substrate (Fig. 9a-b) and penetrate deeply into the resin (Fig. 8b-c). Ascospores narrowly ellipsoidal to cylindrical, one-septate, $8-11 \times 3-4 \mu \mathrm{m}$, appearing smooth under the light microscope (Fig. 9f-g).

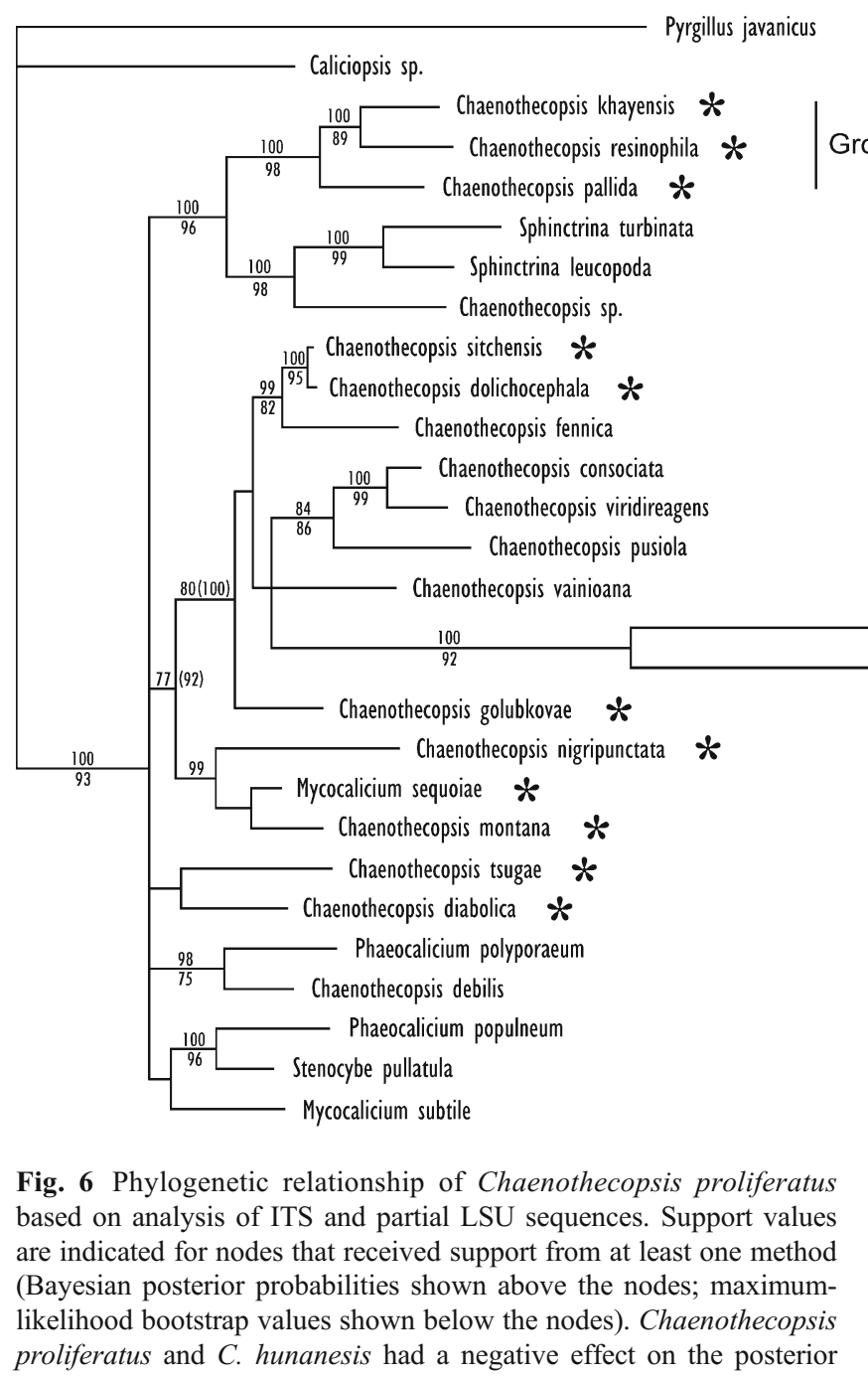



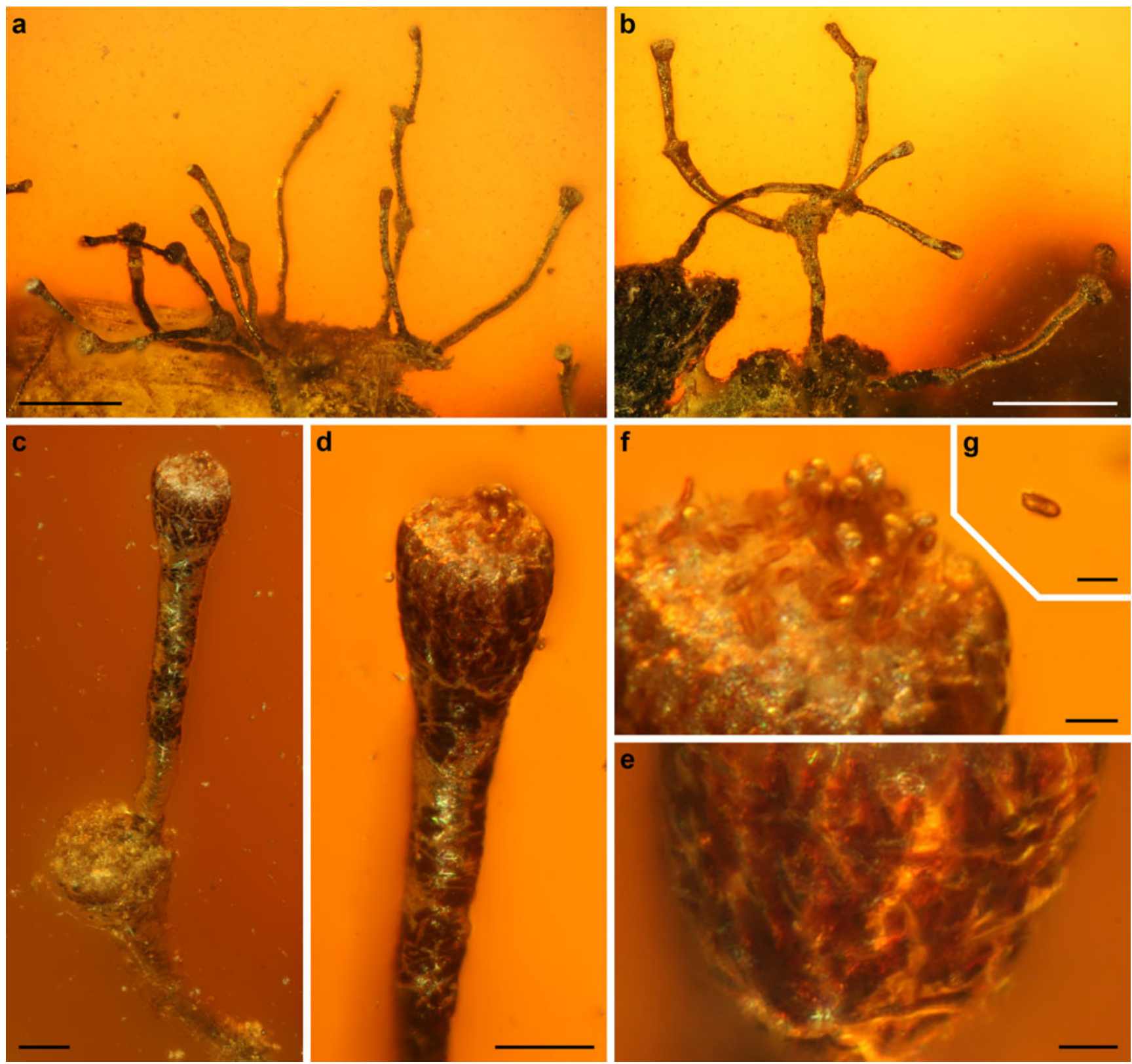

Fig. 7 Fossil Chaenothecopsis from Bitterfeld amber (GZG.BST.27285). a-b Proliferating ascomata. c-d Young ascoma. e Exciple. f Epithecium, note the accumulated ascospores. $\mathbf{g}$ Detached ascospore. Scale bars: $500 \mu \mathrm{m}$ (a and $\mathbf{b}), 50 \mu \mathrm{m}(\mathbf{c}$ and $\mathbf{d})$ and $10 \mu \mathrm{m}(\mathbf{e}-\mathbf{g})$

\section{Discussion}

Taxonomy and evolutionary relationships

In their substrate ecology, general morphology, and in the production of septate ascospores, Chaenothecopsis proliferatus and the two newly described fossils closely resemble each other, as well as several other Chaenothecopsis species from Eurasia and western North-America. The phylogenetic analyses indicate that $C$. proliferatus is closely related to previously known species that live on conifer resin and have one-septate ascospores (Group A in Fig. 6). In as much as both fossils had produced similar spores, and because Baltic and Bitterfeld ambers are fossilized conifer resins, these fossils are likely to belong to this same lineage. No Chaenothecopsis species with aseptate spores were included in this lineage, and the phylogenetic analysis grouped three such species from angiosperm exudates into a different wellsupported clade (Group B in Fig. 6), as a sister group to the two Sphinctrina species.

As the substrate preferences of Mycocaliciales are highly specialized, and spore septation is an important taxonomic character, only resinicolous Chaenothecopsis species with one-septate ascospores are here compared with $C$. 


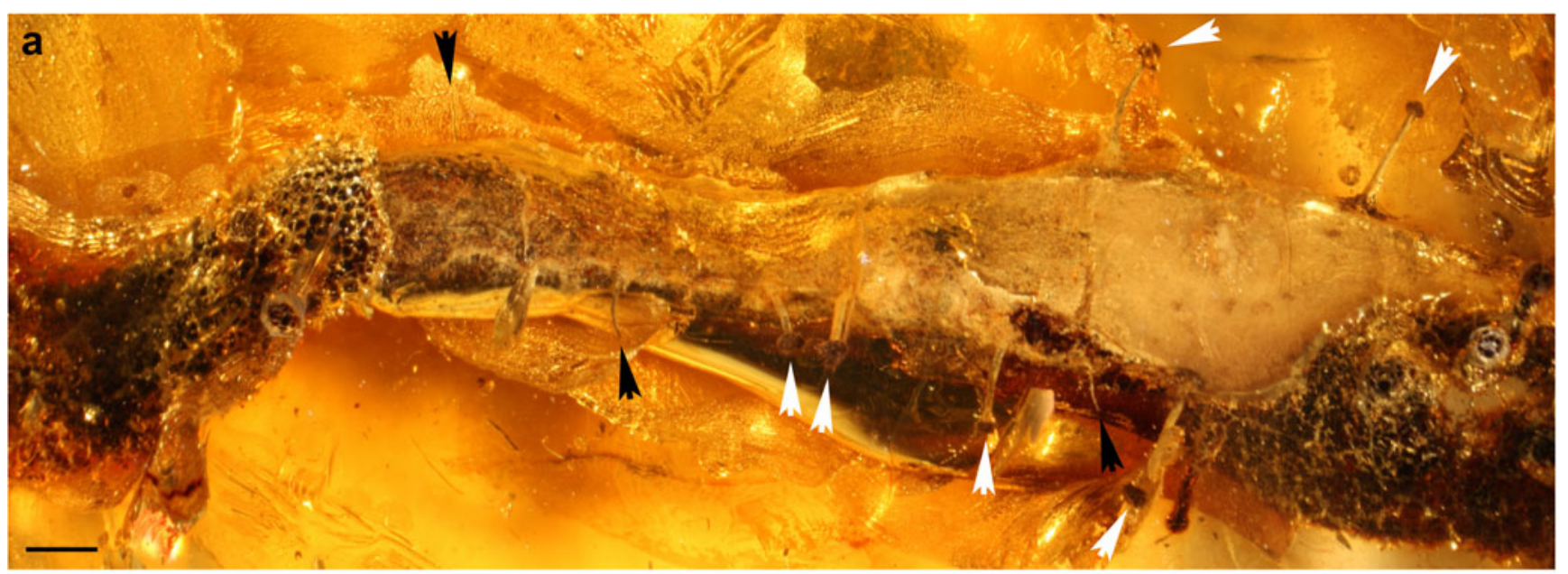

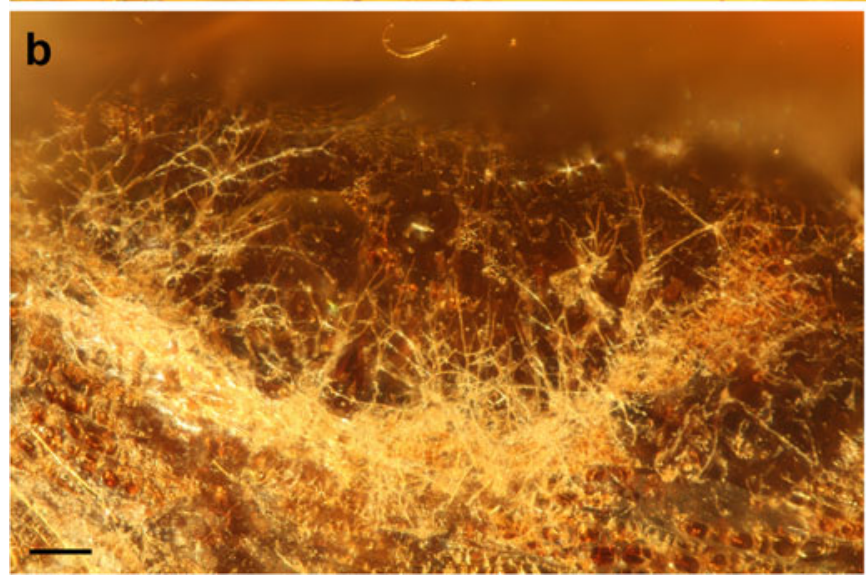

Fig. 8 Overview of the fossil Chaenothecopsis from Baltic amber (GZG.BST.27286). a Ascomata on a stalactite-like piece of solidified resin which was subsequently covered by fresh exudate. Black arrowheads point to young developing ascomata, white arrowheads to

proliferatus and the two fossils. Chaenothecopsis sitchensis Rikkinen, C. nigripunctata Rikkinen, and C. edbergii Selva $\&$ Tibell grow on conifer resin in temperate North America and often produce large and robust ascocarps. C. sitchensis lacks the fast IKI + reactions typical of $C$. proliferatus and has distinctively ornamented ascospores (Rikkinen 1999). C. nigripunctata has larger spores than C. proliferatus and a highly distinctive appearance due to its gray, compound capitula (Rikkinen 2003b). C. edbergii differs from $C$. proliferatus in having a persisting blue MLZ + reaction in the hymenium and a lime green pruina on the surface of its ascomata (Selva and Tibell 1999).

Compared to Chaenothecopsis proliferatus, C. eugenia Titov (Titov 2001) and C. asperopoda Titov (Titov and Tibell 1993) both have smaller spores, very thin septa and a diagnostic stipe structure and coloration. These two species appear to be closely related, but unfortunately we were unable to extract sufficient DNA for sequencing, presumably due to the old age (ca. 20 years) of the type material. Both species have a fast blue IKI + reaction of the

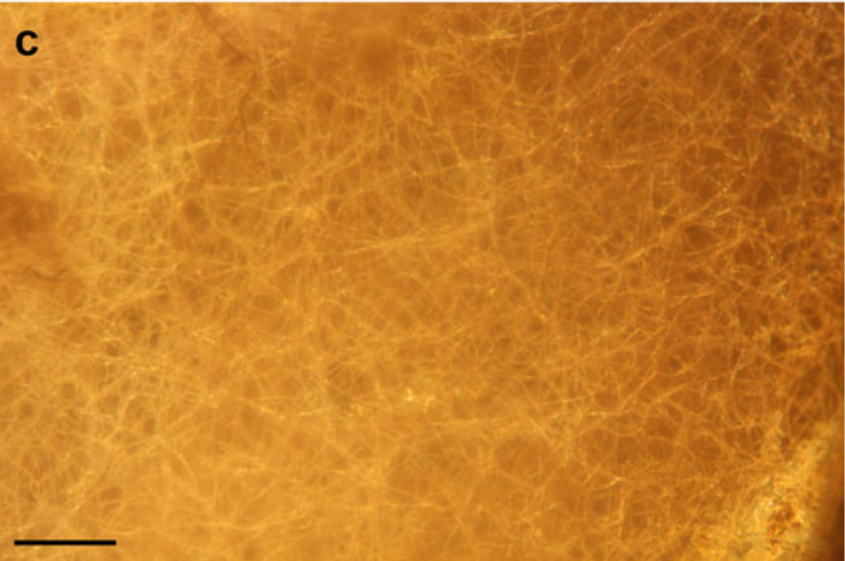

mature ascomata. b Fungal hyphae that grew on and into the stalactite-like resin substrate before it solidified. c Dense mycelium on the old resin flow. Scale bars: $1 \mathrm{~mm}$ (a) and $100 \mu \mathrm{m}$ (b and c)

hymenium and an IKI + red reaction of stipe similar to $C$. proliferatus. The latter color reaction is more easily observed in these species than in C. proliferatus because their stipes are less pigmented.

Chaenothecopsis dolichocephala (Tibell and Titov 1995), C. golubkovae (Titov and Tibell 1993) and C. hunanensis are very similar to $C$. proliferatus. $C$. dolichocephala often produces branched and proliferating fruiting bodies, has similar colorless crystals in the hymenium, and also shares a similar anatomy of the stipe and exciple. However, its ascomata are on average smaller, the stipe is shinier and the ascospores are ornamented. The blue IKI + reaction is very faint or non-existing and the red IKI + reaction occurs only in the lower part of exciple and stipe, if at all. The spore size, epithecial structure and the IKI + color reactions of $C$. golubkovae are more or less identical to those of $C$. proliferatus. However, C. golubkovae is characterized by the highly branched and irregularly shaped hyphae (textura epidermoidea) formed from fused cell walls of the exciple and stipe. $C$. hunanensis has slightly smaller spores with 


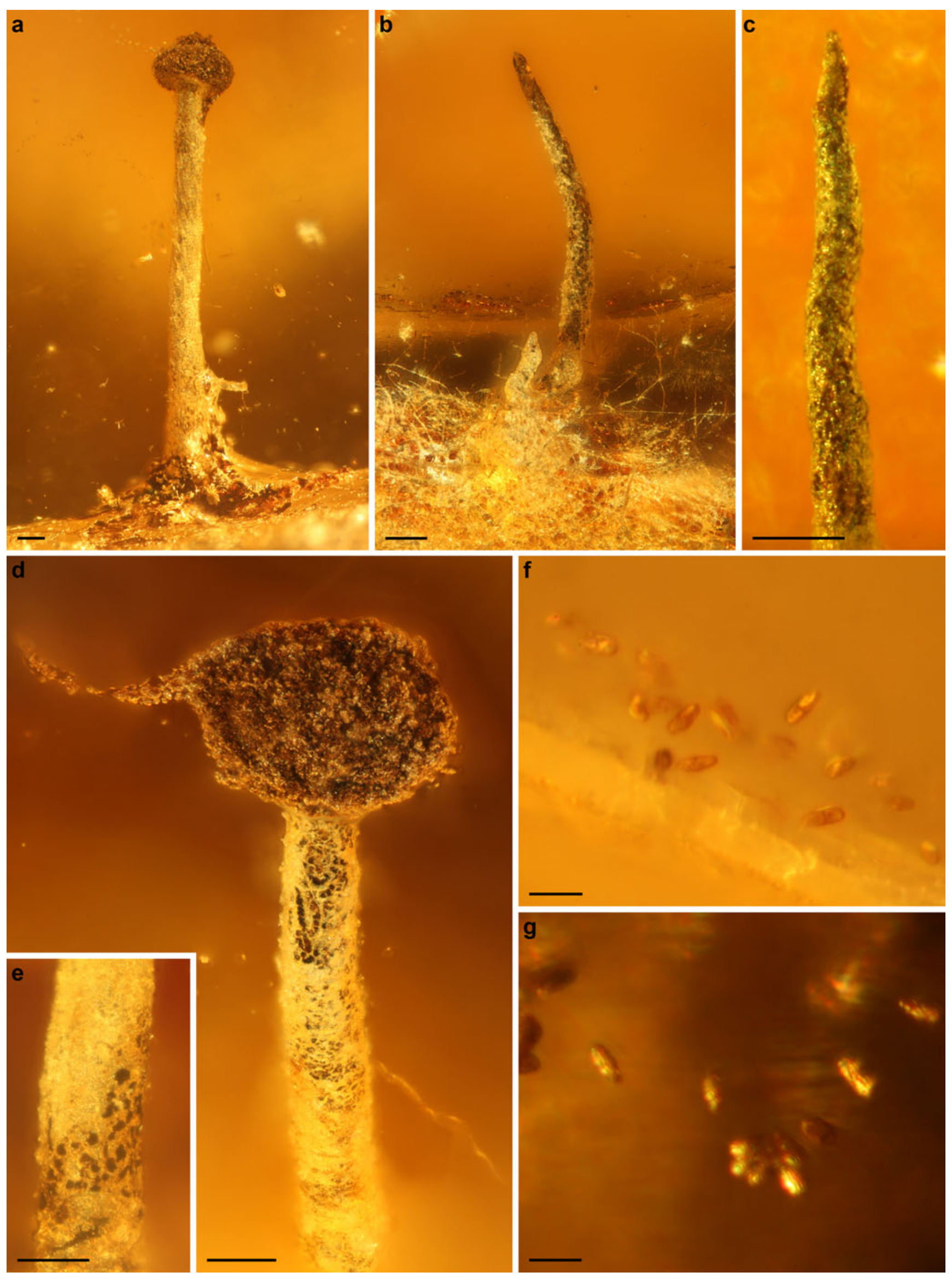


4 Fig. 9 Ascomata and anatomical details of the fossil Chaenothecopsis from Baltic amber (GZG.BST.27286). a Mature ascoma. b Young, developing ascoma and fungal mycelium. c Tip of developing ascoma (compare with Fig. 25 in Rikkinen 2003a). d Capitulum and upper part of stipe; note the accumulated ascospores. Numerous abscised spores extend into the amber matrix in the upper left. e Closer view of stipe surface. f-g Detached ascospores. Scale bars: $100 \mu \mathrm{m}(\mathbf{a}-\mathbf{e})$ and $10 \mu \mathrm{m}$ (f and $\mathbf{g}$ )

thin septa and a different type of epithecium when compared with $C$. proliferatus.

The distinction between $C$. proliferatus, C. dolichocephala, C. golubkovae and C. hunanensis requires study of anatomical details and chemical features that cannot be observed from fossil specimens embedded in amber. Hence, despite their excellent preservation, we do not want to assign the new fossils to any extant species, and we also refrain from assigning them to the previously described Chaenothecopsis bitterfeldensis Rikkinen \& Poinar. However, the four extant species and the three fossils are obviously closely related and most probably belong to the same lineage since $C$. bitterfeldensis resembles $C$. proliferatus and the two newly discovered fossils in ecology and spore type (Rikkinen and Poinar 2000).

The morphological similarities between $C$. proliferatus and the proliferating fossil from Bitterfeld amber are especially striking. The only obvious difference is in the size of the fruiting bodies, with the preserved ascocarps of the fossil being distinctly smaller than typical ascocarps of $C$. proliferatus. Both fungi have relatively slender, commonly branched and proliferating fruiting bodies. The shape and general appearance of the capitula of young fruiting bodies are also identical. The stipes of both fungi are lined by a net of arching and horizontal hyphae (compare Figs. 2a, c and $7 \mathrm{~d}$, e), and these hyphae extend to the epithecium in a similar way. In both fungi, the one-septate and smooth (or minutely punctate) ascospores accumulate on top of the epithecium. All these morphological features together indicate that the fossil is closely related to $C$. proliferatus.

The epithecium of Chaenothecopsis proliferatus is, in places, covered by a thin layer of small crystals. These blade-like structures are typically 1-3 $\mu \mathrm{m}$ long and sharply pointed at both ends (Fig. 4d). While some crystals seem to be partly embedded in the extracellular matrix of fungal hyphae, most appear external. Similar crystals are also present on the upper section of the stipe (Fig. 4b). In their general appearance, the crystals somewhat resemble the needle-like calcium oxalate crystals that cover the hyphal surfaces of some fungi. Such crystals are formed when oxalic acid secreted by the fungus combines with external calcium to produce calcium oxalate (Dutton and Evans 1996). However, only carbon and oxygen were detected from the epithecium surface of $C$. proliferatus in EDX analyses.
Occurrence and ecological role of proliferating ascocarps

The ascomata of many species of Mycocaliciales can occasionally have a capitulum in which the apothecial disk is divided into several distinct regions or lobes. Asci tend to first mature in the central sections of the hymenia and when more asci mature, the hymenium expands and the capitulum surface become increasingly convex. Irregularities in ascus production can easily lead to the development of several hymenial convexities or lobes per capitulum. Many Chaenothecopsis species can also occasionally produce branched ascocarps, and these structures appear to be especially common in resinicolous species with long and slender stipes, such as $C$. oregana Rikkinen and $C$. diabolica Rikkinen \& Tuovila. However, ascocarp braching is not confined only to resinicolous species, but also occurs in some lichen-associated and lignicolous species such as $C$. haematopus Tibell and C. savonica (Räsänen) Tibell, which typically grow on lignum in shaded microhabitats. Branching also occurs in some species of Mycocalicium Vain., Phaeocalicium A.F.W. Schmidt and Stenocybe Nyl. ex Körb. For example, Stenocybe pullatula (Ach.) Stein can produce several capitula from the same stipe, with the youngest at the tip and the older, senescing capitula appearing as a whorl directly below. This species produces ascocarps on the bark of Alnus species.

In the resinicolous Chaenothecopsis nigripunctata branching mainly occurs very close to the tip of the stipe, with each short branch forming a separate apothecial head. Profuse branching often leads to the development of compound capitula, consisting of up to twelve partially contiguous apothecial heads (Rikkinen 2003b). Mycocalicium sequoiae Bonar also produces clusters of apothecial heads on a common stipe (Bonar 1971). However, in this species the stipes tend to branch lower and hence have longer branches and less confluent apothecial heads than in C. nigripunctata. Also the related C. montana Rikkinen can produce branched ascocarps, but more rarely than the other two species (Tuovila et al. 2011b).

While the ascomata of $C$. nigripunctata and its closest relatives mainly branch from the upper part of the stipe, their ascocarps do not usually form multi-layered groups via branching and proliferation through the hymenium in the way exhibited by the proliferating fossil from Bitterfeld amber and many specimens of $C$. proliferatus. However, similar branching is quite common in the resinicolous $C$. dolichocephala and $C$. sitchensis, both of which usually have very narrow and long stipes. This shared morphology might represent an adaptation to growing near active resin flows: the perennial ascocarps can effectively rejuvenate in situations where they happen to be partly submerged in fresh exudate. All three species commonly live on cankers and wounds which exude resin over extended periods. 
It seems unlikely that the ascomata of resinicolous Chaenothecopsis species could rejuvenate after being rapidly and completely submerged in fresh sticky resin. Even the fossil specimens had first produced fruiting bodies on hardened resin and then had subsequently been covered by a thick layer of fresh exudate. This raises the question of what then triggers the proliferation in partly submerged ascocarps and those ascocarps only growing close to fresh resin. It has been shown that some fungi react to the volatile compounds produced by other fungi when competing for resources (Evans et al. 2008). It is also known that fresh resin contains high levels of volatile compounds, mainly monoterpenes and sesquiterpenes, when compared to older, semisolid exudate, and that the hardening of resin is directly related to the loss of such compounds (e.g. Langenheim 2003; Ragazzi and Schmidt 2011). An ability to detect and respond to the presence of volatile resin compounds in the environment would give the Chaenothecopsis species time to prepare for a potential burial in freshly exuding resin. It seems feasible that some resinicolous fungi could begin to branch when the concentration of volatile resin compounds in their typically sheltered microenvironment is sufficiently high as to indicate that a fresh resin flow may be imminent. In other fungi the differentiation of fruiting bodies is commonly triggered by the perception of some change in environmental conditions, such as light, $\mathrm{pH}$, oxygen etc. (Busch and Braus 2007).

The hyphae of extant resinicolous fungi commonly penetrate and grow into semisolid resin. Evidence of inward growth of fungal hyphae is also preserved in numerous worldwide amber fossils since the Paleocene (personal observation), but no evidence of a similar capability has yet been found prior to the Cretaceous-Paleogene boundary. Cretaceous amber pieces from several different deposits may contain abundant filaments that grew from the resin surface into liquid resin, but all of these have been identified as filamentous prokaryotes (see Schmidt and Schäfer 2005; Schmidt et al. 2006; Girard et al. 2009a, b; Beimforde and Schmidt 2011), not as fungal hyphae. This suggests that this special niche was either occupied by prokaryotes in the Mesozoic or that Chaenothecopsis species (if already existent) and other ecologically similar fungi did not yet exploit resin substrates.

\section{Conclusions}

Fossil evidence of inward growth of fungal hyphae into plant exudates has not been identified from Mesozoic ambers, suggesting a relatively late occupation of such substrates by ascomycetes. Even so, resinicolous Chaenothecopsis species were well adapted to their niche by the Eocene and the ecology and morphology of these fungi has since remained unchanged. The Oligocene fossil had produced proliferating ascomata identical to those of the newly described species from China and its extant relatives. This morphology may represent an adaptation to life near exuding resin: the proliferating ascomata can effectively rejuvenate if partly overrun by fresh exudate. While many extant Chaenothecopsis species live on lichens and/or green algae, the fossils and the sporadic occurrence of resinicolous taxa in several distantly related extant lineages suggests that the early diversification of Mycocaliciales may have occurred on plant substrates.

Acknowledgments The field work in Hunan Province was done in cooperation with the Forestry Department of Hunan Province and its Forest Botanical Garden, and the Department of Biosciences (formerly Department of Ecology and Systematics), and the Botanical Museum, University of Helsinki. We thank Timo Koponen who's Academy of Finland project (no 44475) made the field work possible. Jörg Wunderlich (Hirschberg and der Weinstraße, Germany) kindly provided an amber piece of his collection for this study and Hans Werner Hoffeins (Hamburg) embedded the Baltic amber piece in polyester resin. We are grateful to Eugenio Ragazzi (Padova) for discussion about resin chemistry, to Dorothea Hause-Reitner (Göttingen) for assistance with field emission microscopy and to Leyla J. Seyfullah (Göttingen) for comments on the manuscript. Marie L. Davey (University of Oslo) provided indispensable help with sequencing difficult samples and advice on the molecular work. The work of H.T. was supported by research grants from the Jenny and Antti Wihuri Foundation and Ella and Georg Ehrnrooth Foundation. This is publication number 92 from the Courant Research Centre Geobiology that is funded by the German Initiative of Excellence.

Open Access This article is distributed under the terms of the Creative Commons Attribution License which permits any use, distribution, and reproduction in any medium, provided the original author (s) and the source are credited.

\section{References}

Beimforde C, Schmidt AR (2011) Microbes in resinous habitats: a compilation from modern and fossil resins. Lect Notes Earth Sci 131:391-407

Beimforde C, Schäfer N, Dörfelt H, Nascimbene PC, Singh H, Heinrichs J, Reitner J, Rana RS, Schmidt AR (2011) Ectomycorrhizas from a Lower Eocene angiosperm forest. New Phytol 192:988-996

Blumenstengel H (2004) Zur Palynologie und Stratigraphie der Bitterfelder Bernsteinvorkommen (Tertiär). Exkursionsführer und Veröffentlichungen der Deutschen Gesellschaft für Geowissenschaften 224:17

Bonar L (1971) A new Mycocalicium on scarred Sequoia in California. Madranõ 21:62-69

Busch S, Braus GH (2007) How to build a fungal fruit body: from uniform cells to specialized tissue. Mol Microbiol 64:873-876

Castresana J (2000) Selection of conserved blocks from multiple alignments for their use in phylogenetic analysis. Mol Biol Evol 17:540-552

Drummond AJ, Ashton B, Buxton S, Cheung M, Cooper A, Duran C, Field M, et al. (2011) Geneious v5.4. Retrieved from www.geneious.com 1 May 2011

Dunlop J (2010) Bitterfeld amber. In: Penney D (ed) Biodiversity of Fossils in Amber. Siri Scientific Press, Manchester, pp 5768 
Dutton MV, Evans CS (1996) Oxalate production by fungi: its role in pathogenicity and ecology in the soil environment. Can J Microbiol 42:881-895

Evans JA, Eyre CA, Rogers HJ, Boddy L, Müller CT (2008) Changes in volatile production during interspecific interactions between four wood rotting fungi growing in artificial media. Fungal Ecol $1: 57-68$

Gardes M, Bruns TD (1993) ITS primers with enhanced specificity for basidiomycetes - application to the identification of mycorrhizae and rusts. Mol Ecol 2:113-118

Girard V, Breton G, Brient L, Neraudeau D (2009a) Sheathed prokaryotic filaments, major components of mid-Cretaceous French amber microcoenoses. J Paleolimnol 42:437-447

Girard V, Schmidt AR, Struwe S, Perrichot V, Breton G, Néraudeau D (2009) Taphonomy and palaeoecology of mid-Cretaceous amberpreserved microorganisms from southwestern France. In: Perrichot V, Néraudeau D (eds) Cretaceous ambers from southwestern France: geology, taphonomy, and palaeontology. Geodiversitas 31:153-162

Hoffeins HW (2001) On the preparation and conservation of amber inclusions in artificial resin. Pol J Entomol 70:215-219

James TY, Kauff F, Schoch CL et al (2006) Reconstructing the early evolution of Fungi using a six-gene phylogeny. Nature 443:818822

Katoh K, Toh H (2008) Recent developments in the MAFFT multiple sequence alignment program. Brief Bioinform 92:86-98

Knuth G, Koch T, Rappsilber I, Volland L (2002) Concerning amber in the Bitterfeld region -geologic and genetic aspects. Hallesches Jahrb Geowiss 24:35-46

Koponen T, Enroth J, Fang YM, Huttunen S, Hyvönen J, Ignatov M, Juslén A, Lai MJ, Piippo S, Potemkin A, Rao PC (2000) Bryophyte flora of Hunan Province, China, 1. Bryophytes from Mangshan Nature Reserve and Wulingyuan Global Cultural Heritage Area. Ann Bot Fenn 37:11-39

Koponen T, Cao T, Huttunen S, Hyvönen J, Juslén A, Peng C, Piippo S, Rao PC, Vána J, Virtanen V (2004) Bryophyte Flora of Hunan Province, China, 3: Bryophytes from Taoyuandong and Yankou Nature Reserves and: Badagongshan and Hupingshan National Nature Reserves, with additions to floras of Mangshan Nature Reserve and Wulingyuan Global Cultural Heritage Area. Acta Bot Fenn 177:1-47

Kumar S, Skjæveland Å, Orr R, Enger P, Ruden T, Mevik BH, Burki F et al (2009) AIR: a batch-oriented web program package for construction of supermatrices ready for phylogenomic analyses. BMC Bioinforma 10:357

Langenheim JH (2003) Plant resins: chemistry, evolution, ecology and ethnobotany. Timber Press, Portland

Müller K, Müller J, Neinhuis C, Quandt D (2010) PhyDE—Phylogenetic Data Editor. www.phyde.de. Retrieved 15 October 2011

Posada D (2008) jModelTest: Phylogenetic Model Averaging. Mol Biol Evol 25:1253-1256

Pratibha J, Amandeep K, Shenoy BD, Bhat DJ (2011) Caliciopsis indica sp. nov. from India. Mycosphere 1:65-72

Ragazzi E, Schmidt AR (2011) Amber. In: Reitner J, Thiel V (eds) Encyclopedia of Geobiology. Spinger, Dordrecht, pp 24-36

Rehner S, Samuels GJ (1994) Taxonomy and phylogeny of Gliocladium analyzed from nuclear large subunits ribosomal DNA sequences. Mycol Res 98:625-634

Rikkinen J (1999) Two new species of resinicolous Chaenothecopsis (Mycocaliciaceae) from western North America. Bryologist 102:366-369

Rikkinen J (2003a) Calicioid lichens and fungi in the forests and woodlands of western Oregon. Acta Bot Fenn 175:1-41

Rikkinen J (2003b) Chaenothecopsis nigripunctata, a remarkable new species of resinicolous Mycocaliciaceae from western North America. Mycologia 95:98-103
Rikkinen J, Poinar G (2000) A new species of resinicolous Chaenothecopsis (Mycocaliciaceae, Ascomycota) from 20 million year old Bitterfeld amber, with remarks on the biology of resinicolous fungi. Mycol Res 104:7-15

Ronquist F, Huelsenbeck JP (2003) Bayesian phylogenetic inference under mixed models. Bioinformatics 19:1572-1574

Schmidt AR, Dörfelt H (2007) Evidence of Cenozoic Matoniaceae from Baltic and Bitterfeld amber. Rev Palaeobot Palynol 144:145-156

Schmidt AR, Schäfer U (2005) Leptotrichites resinatus new genus and species, a fossil sheathed bacterium in alpine Cretaceous amber. J Paleontol 79:184-193

Schmidt AR, Ragazzi E, Coppellotti O, Roghi G (2006) A microworld in Triassic amber. Nature 444:835

Schmidt AR, Jancke S, Lindquist EE, Ragazzi E, Roghi G, Nascimbene P, Schmidt K, Wappler T, Grimaldi DA (2012) Arthropods in amber from the Triassic Period. PNAS 109:14796-14801

Selva SB, Tibell L (1999) Lichenized and non-lichenized calicioid fungi from North America. Bryologist 102:377-397

Standke G (1998) Die Tertiärprofile der Samländischen Bernsteinküste bei Rauschen. Schriftenr Geowiss 7:93-133

Standke G (2008) Bitterfelder Bernstein gleich Baltischer Bernstein?Eine geologische Raum-Zeit-Betrachtung und genetische Schlußfolgerungen. In: Rascher J, Wimmer R, Krumbiegel G, Schmiedel S (eds) Bitterfelder Bernstein versus Baltischer Bernstein - Hypothesen, Fakten, Fragen. Exkursionsführer und Veröffentlichungen der Deutschen Gesellschaft für Geowissenschaften 236:11-33

Tibell L, Titov A (1995) Species of Chaenothecopsis and Mycocalicium (Caliciales) on exudate. Bryologist 98:550-560

Tibell L, Vinuesa M (2005) Chaenothecopsis in a molecular phylogeny based on nuclear rDNA ITS and LSU sequences. Taxon 54:427-442

Titov A (2001) Further notes on calicioid lichens and fungi from the Gongga Mountains (Sichuan, China). Lichenologist 33:303-314

Titov A (2006) Mikokalizievye griby (porjadok Mycocaliciales) Golarktiki [Mycocalicioid fungi (the order Mycocaliciales) of Holarctic]. KMK Scientific Press, Moskva

Titov A, Tibell L (1993) Chaenothecopsis in the Russian Far East. Nord J Bot 13:313-329

Tuovila H, Cobbinah JR, Rikkinen J (2011a) Chaenothecopsis khayensis, a new resinicolous calicioid fungus on African mahogany. Mycologia 103:610-615

Tuovila H, Larsson P, Rikkinen J (2011b) Three resinicolous North American species of Mycocaliciales in Europe with a re-evaluation of Chaenothecopsis oregana Rikkinen. Karstenia 51:37-49

Vilgalys R, Hester M (1990) Rapid genetic identification and mapping of enzymatically amplified ribosomal DNA from several Cryptococcus species. J Bacteriol 172:4238-4246

Vinuesa M, Sanchez-Puelles JM, Tibell L (2001) Intraspecific variation in Mycocalicium subtile (Mycocaliciaceae) elucidated by morphology and the sequences of the ITS1-5.8S-ITS2 region of rDNA. Mycol Res 105:323-330

Wang Z, Binder M, Hibbett DS (2005) Life history and systematics of the aquatic discomycete Mitrula (Helotiales, Ascomycota) based on cultural, morphological, and molecular studies. Am J Bot 92:1565-1574

Weitschat W (1997) Bitterfelder Bernstein-ein eozäner Bernstein auf miozäner Lagerstätte. Metalla 66:71-84

White TJ, Bruns TD, Lee S, Taylor JW (1990) Amplification and direct sequencing of fungal ribosomal RNA genes for phylogenetics. In: Innis MA, Gelfand DH, Sninsky JJ, White TJ (eds) CR Protocols: A Guide to Methods and Applications. Academic, New York, pp $312-322$

Zwickl DJ (2006) Genetic algorithm approaches for the phylogenetic analysis of large biological sequence datasets under the maximum likelihood criterion. Dissertation, The University of Texas 